\title{
Proteus mirabilis
}

National Cancer Institute

\section{Source}

National Cancer Institute. Proteus mirabilis. NCI Thesaurus. Code C86019.

A Gram-negative, facultatively anaerobic bacterium with swarming motility, and urease activity. 